training service for research workers, a documentation service, and an inventions service.

The documentation centre not only publishes its own material, but also subsidizes the publication of books and periodicals. It publishes a Bulletin Analytique, an abstracting journal with two unique features. It not only covers all the objective sciences, but has also a section devoted to philosophical studies, and it notifies unpublished matter deposited in the archives of the Centre National.

The Commission des Inventions has some kinship with the National Research Development Corporation in Britain; but may fairly claim at the moment to be in some respects the more advanced. It gives assistance to inventors from the Centre National, or from outside bodies, or to individuals, in all forms from technical advice to financial help in exploitation. Its small budget (some $\mathfrak{1 0 , 0 0 0}$ last year) limits its scope, but it is dealing with some four hundred inventions annually, and it can initiate special grants, such as that made for the development of the calculating machine of the Institut Blaise Pascal.

Such in outline is the form taken by official research organisations in France ; further information can be obtained from the Scientific Office of the French Embassy, 58 Knightsbridge, London, S.W.1.

Organisation does not make research, and the efficacy of the French plan must be judged by results : advances in natural knowledge, advances in material well-being, the overall balance between different fields, and so on. At the least, one may be grateful that the exhibition at the Science Museum has provided an opportunity of judging one other type of result, namely, that of advances in instrumental technique.

Instrument design is subject to fashion, and as now materials and resources become available, style and external appearance change. French fashion would appear now to favour bright colours, open access, easy substitution of alternative components and a much more robust construction all round than we have expected from commercial French instruments in the past.

Design, of course, is partly an individual function, partly a matter of influences, and it is more than amusing to note the differences in style between the different groups. One may certainly detect an American element in the atomic energy exhibits. The subject-matter is irrelevant here. The influence is seen in such details as style of name-plate, shape and size of control knobs and much else which reflects mere habit-a reflexion in turn of the close association which specialists in this field had with British and American activity for so long.

Although outside influences are apparent in the section contributed by the French instrument industry, family tradition, allied with long Continental practice, gives many of the instruments shown an unmistakable character.

These are superficial considerations. The technical accomplishment of French instrument technology is demonstrated by the Fonbrune micromanipulator, the Desvignes monochromator (which uses a single element but is comparable in performance with a double monochromator of conventional design, and has higher luminosity), an excellent recording microphotometer, a compact short-period seismograph, a single-cylinder experimental internal combustion engine for combustion and lubrication studies, and a micro tensile test machine for studying the properties of single fibres. In all these, fitness for purpose is clearly evident, as it is in many of the other instruments displayed. It is this same quality which gives interest to many other instruments for which no claim of originality is made; for example, the analytical mass spectrograph and the multi-unit polarograph shown by the Commissariat a l'Energie Atomique.

The narrow spaces of an exhibition stand focus attention on the laboratory-bench aspect of experimental technique ; but one must remember that some investigations necessarily require apparatus of large dimensions. A set of photographs, some striking for the beauty of the photography, showed the Modane high-speed wind-tunnel project of the Office National d'Etudes et de Recherches Aeronautiques. The size of the budget for this enterprise-some millions of pounds-will remind us that the French can match elegance with boldness when the aim is clearly conceived.

The lasting results of this exhibition cannot be assessed yet. Its appeal was not to the large majority looking for handy routine tools, but rather to the few who seek help in seeing science whole. If, as has been suggested, an exhibition of British scientific instruments is held in Paris, the other half of a pattern of joint effort will fall into place. As near neighbours, Great Britain and France have no choice but to collaborate in many spheres. Collaboration. and understanding in the sphere of science hold a potential for good which exhibitions of this sort do much to advance towards ultimate realization.

Frank Greenaway

\section{YUKON-ALASKA EXPEDITION OF THE ARCTIC INSTITUTE OF NORTH AMERICA}

\author{
By Prof. N. E. ODELL
}

University of Otago, Dunedin, New Zealand

$\mathrm{D}$ URING this past summer (1949) the Aretic Institute of North America (New York branch) organised the second instalment of its programme of field research within the high interior of the St. Elias Range on the international boundary between Yukon Territory and Alaska. The first instalment took place during the field-season of 1948, and a summary of the results attained are given by Walter A. Wood, the leader and organiser, in Arctic (1, No. $2 ; 1948$ ), the journal of the Institute. Referred to as "Project Snow Cornice", the object of this enterprise was glaciological work, as well as geological and meteorological, in a region scantily known and notoriously inaccessible. But the prime motive in the first instance had been programmes of intensive glacio. logical investigation, such as those which have been conducted in Europe, Greenland and Spitsbergen under Scandinavian, British and Swiss auspices, and which have been lacking so far anywhere in North America.

A high intermontane basin within the St. Elias Range, situated on the Yukon side of the border, and occupied by the Seward Glacier (or firn-field, sensu stricto), was chosen as the most suitable locality for these glaciological observations. Such an area of accumulation, approximately 750 square miles in 
extent, which is the main feeder of the great piedmont Malaspina Glacier, appeared admirable from the point of view of modorn glacier-regimen studies. However, such an inaccessible and difficult region, sixty miles at least from the coast, can only in practice be approached or utilized for this purpose by the employment of aircraft. A 'Norseman' aeroplane, fitted with special retractable wheel-ski landing gear, was the answer to the transport problem, and in the hands of the experienced 'bush' pilot, Maurice King, it fulfilled all expectations, even to the extent ultimately of having its possible 'ceiling' improved to an altitude of more than fifteen thousand feet, when in the process of reconnoitring Mt. Vancouver.

From a coastal base at Yakutat, with its airfield of the Civil Aeronautics Authority, the first flight was made in mid June up to the Seward firn-field, where again was established an advanced base for the work of the Expedition. Situated at an altitude of about six thousand feet, nearly fifteen feet of snow had fallen in this locality during the winter of 1948-49, as we were able to determine during the excavation of a cache of stores left in 1948; but precipitation must be heavy at all times in this region. At Yakutat on the coast the average over forty-two years has been $\mathbf{1 3 4}$ inches of rainfall, with a highest annual of 168 inches within that period; while during July 1, 1948-July 1, 1949, as much as 162 inches was recorded.

It was in the vicinity of our 'airstrip' camp on the Seward firn-field that a great part of the glaciological researches was carried out under the direction of Prof. R. P. Sharp, of the California Institute of Technology. These investigations, in continuation of those conducted during the summer of 1948, comprised thermal regimen, firn density and structure, free-water content, melt-water movement, ablation and accumulation. Measures of the thickness of firn and glacier-ice were determined, or attempted, by seismic survey, radar, and gravity meter, but the present technique used, in the case of radar in particular, has so far proved unsatisfactory. Prof Sharp and his party of five specialists have yet, of course, to analyse fully all their field observations and results. But a promising start has been made with what it is hoped may be a long-term programme of glaciological research to be continued in subsequent seasons on the Seward firn-field as and when circum. stances permit.

On the Malaspina Glacier itself, in the vicinity of the coastline, Dr. Henri Bader carried out some crystallographic and structural studies of the stagnant ice of this piedmont mass, and it is anticipated that some interesting results mav accrue from these investigations, which it is hoped may be continued in the future. A feature of special interest here is the heavy growth of sitka spruce and western hemlock trees, up to seventy-five feet high and thirty inches in diameter, which has colonized the marginal tract of the Malaspina Glacier. Yet in a convenient exposure it cou'd be seen that the ablation mantle of moraine and debris covering the ice, upon which these large trees were growing, had an average thickness of only 2-3 feet. A number of these trees were cored by a Swedish increment borer. and their ages were found to vary from about fifty years to as much as ninety-nine years in the case of the oldest discovered.

As to the solid.rock geology, with which I was principally concerned, an examination was made of many 'island' outcrops in, as well as the great mountain walls surrounding, the Seward firn-field from our advanced base situated on a nunatak, or rognan, near the foot of Mt. Vancouver. It was sometimes necessary to travel a dozen miles or more on skis over the surface of the vast firn-field to reach particular outcrops, and bad weather and adverse terrain often hampered both topographical and geological mapping. The services of our aeroplane were called upon for visiting the remoter areas to the westward and northward, although conditions of landing on the snowy or icy surface were at times very difficult and required the utmost judgment. In brief, it can be said that the heart of the St. Elias Range consists of a metamorphic series of sedimentary origin, mainly pelitic and cale, and in all probability of Palæozoic and Mesozoic age. Into this series has been intruded an igneous facies which varies from granite to grano-diorite and diorite, and it is usually gneissose in structure in the field. A later suite of dolerite dykes cuts the whole complex. The immense mountain masses of Mt. Logan, 19.850 ft. (the highest summit in Canada), Mt. St. Elias, $18,008 \mathrm{ft}$., and Mt. Vancouver, 15,800 ft., are examples of such acid intrusive occurrence, which by their greater durability, aided possibly by differential uplift, have maintained their pre-eminence. In the case of Mt. Vancouver, of which four of us made an arduous eight.days' ascent, and until then the highest unclimbed mountain in North America, it was found that the summit outcrops consisted of a particularly tough arkose or greywacke, much fortified by local aplitic bodies.

It is of interest to recall that as long ago as 1891-92 Prof. I. C. Russell crossed the Malaspina ice-sheet and examined the southern flanks of the St. Elias Range, and in doing so he made the important discovery of Pleistocene (and Pliocene ?) beds having been elevated to some five thousand feet above sealevel. But no one has since followed up his important work. That great elevation has taken place in this region seems to be beyond doubt. Moreover, there is evidence otherwise to suggest that this was, at least in part, probably subsequent to the waning of the much greater Pleistocene glacierization, which appears to have filled the Seward basin to a thickness at least five thousand feet in excess of that of the present day. On the western ridge of Mt. Vancouver I found a moraine-like deposit as high as thirteen thousand feet; but this I am disinclined to regard as firm and unequivocal evidence of the maximum stand of the regional ice-sheet.

Space does not here permit of more than mention of the other interesting discoveries mede in the course of the work of the Expedition. The fact that spiders, butterflies, moths, a variety of birds, including even humming-birds, shou'd be found in these remote, frigid and elevated mountain fastnesses, apart from a whole range of alpine and arctic plants. mosses, etc., raises all kinds of questions of migration and indeed origin. Not the least curious discovery, made by me near a camp at about six thousand feet beneath the immense southern wall of Mt. Logan. was that of ice- or glacier-worms, to which occurrence reference has already been made in Nature (December 24,1949 , p. 1098). So much mirth and banter has been engendered. even among men of science. by the mention of ice-worms that a peculiar gratification was experienced in this one discovery alone. How ever, in such a spectacular region there is no need to look for specific thrills, and ice-worms constitute perhaps the least of these. 